\title{
Potential Peat Clay for Minerals Source Utilized as Adsorbent and Catalyst
}

\author{
Agus Mirwan ${ }^{1, *}$, Meilana Dharma Putra $^{1}$, and Riani Ayu Lestari ${ }^{1}$ \\ ${ }^{1}$ Chemical Engineering Department, Lambung Mangkurat University, Banjarmasin 70123, Indonesia
}

\begin{abstract}
The existence of peat clay is scattered in many parts of the world with the huge amount. The high compound of minerals in the peat clay can be potentially used as adsorbent and catalyst. This research aims to study the composition of peat clay and functional group of the compound in the peat clay. The characterization of $x$-ray fluorescence (XRF), fourier transform infrared spectroscopy (FTIR), x-ray diffraction (XRD), and scanning electron microscope-energy dispersive x-ray (SEMEDX) were assigned to compare the sample before and after calcination process at $700{ }^{\circ} \mathrm{C} 120 \mathrm{~min}$. FTIR analysis showed the presence of quartz, kaolinite, hematite, illite in peat clay. The results of XRF analysis showed that chemical composition of peat clay was dominantly in the form of silica oxide $(18 \%)$, aluminum oxide $(7 \%)$, and iron oxide $(15 \%)$. The amount of compounds was observed to increase to be $32 \%, 18 \%$ and $11 \%$, respectively after calcinations. XRD analysis confirmed the presence of this mineral in the peat clay. SEM analysis showed flake structure of peat clay with EDX which indicated composition of the dominant element namely the presence of $\mathrm{Al}, \mathrm{Si}$, and $\mathrm{Fe}$ before and after calcination. This high amount of minerals in peat clay led to potential source to be utilized as adsorbent for removing the pollutant or as and catalyst for chemical process.
\end{abstract}

\section{Introduction}

Peat clay is land scattered in many parts of the world. Peat clay has the main chemical composition of $\mathrm{Si}, \mathrm{Fe}, \mathrm{Al}$ which is potential as coagulant, adsorbent, and catalyst in various applications. It can anticipate the still expensive source of catalyst from commercial materials. The use of peat clay as an adsorbent and catalyst becomes an attractive potential.

The clay has a layered structure and is classified into several classes such as smectite (montmorillonite, saponite), mica (illite), kaolinite, serpentine, pylophyllite (talc), vermiculite and sepiolite [1]. Among these classifications, montmorillonite clays have the highest cation exchange capacity and the largest surface area [2]. Peat clay is a type of clay having a layered structure; it is categorized as montmorillonite. Peat clay is an organic clay containing compounds $\mathrm{Al}_{2}\left(\mathrm{SO}_{4}\right) \mathrm{H}_{2} \mathrm{O}$; it has a function as a coagulant for removing most of the dissolved organic substances, microorganisms (plankton and bacteria) and other compounds. The compounds significantly cause color and turbidity of peat water. In

\footnotetext{
* Corresponding author: agusmirwan@ulm.ac.id
} 
addition, peat clay has potential uses as an adsorbent and catalyst; since it generally contains the main chemical composition of aluminum oxide, silica oxide, and iron oxide [3]. The adsorption ability in clay comes from a negative charge on mineral structures that can absorb positively charged species. Peat clay has some cross sections of underground layers based on different depth and has major minerals such as kaolinite, pyrite, illite and halloysite.

Hegazy et al [4] expressed that the clay had five crystalline phases, namely kaolinite $\left(\mathrm{Al}_{2} \mathrm{Si}_{2} \mathrm{O}_{5}(\mathrm{OH})_{4}\right)$, montmorillonite $\left(\left(\mathrm{Na}_{\mathrm{x}}(\mathrm{Al}, \mathrm{Mg})_{2} \mathrm{SiO}_{10}(\mathrm{OH})_{2} \mathrm{ZH}_{2} \mathrm{O}\right)\right)$, quartz $\left(\mathrm{SiO}_{2}\right)$, microcline $\left(\mathrm{KAlSi}_{3} \mathrm{O}_{8}\right)$, and illite-montmorillonite $\left(\mathrm{K}-\mathrm{Al}_{4}(\mathrm{SiAl})_{8} \mathrm{O}_{20}(\mathrm{OH})_{4} \times \mathrm{XH}_{2} \mathrm{O}\right)$. The same thing also expressed by Nayak and Singh [2] that the main phase of crystalline clay minerals consists of quartz, kaolinite, hematite, illite, and tridymite. The dominant chemical compounds in peat clay were silica oxide, aluminum oxide and iron oxide ranged 28.98 to $65.32 \%$-wt, 13.89 to $43.00 \%$-wt, and 0.40 to $20.13 \%$-wt respectively [3], [4] depending on the location and depth. The position of peat clay lies at a depth of about 1.5 to 3.0 meters from peat soil [3]. In addition, thermal treatment of clay within the temperature range of $500-900^{\circ} \mathrm{C}$ can affect the dehydration transformation from kaolinite to amorphous metakaolinite thereby increasing the reactivity of the clay [5].

The aim of the research is to study the composition of peat clay and functional group of the compound in the peat clay. The peat clay before and after calcination were evaluated using analytical techniques of XRF, FTIR, XRD, and SEM-EDX. The study of compound in peat clay would be able to open the way for its uses and utilization as adsorbent for removing toxic or undesired compounds in wastewater and catalyst for producing many industrial products.

\section{Methodology/ Experimental}

Peat clay was obtained from Village of Peat, Subdistrict of Peat, District of Banjar, South Kalimantan, Indonesia and in the depths about 3.0 meters from the surface of the earth. Peat clay was washed and dried under direct sunlight for 48 hours. After drying and milling, peat clay particles were separated by sieving size of 325 mesh standard sieve based on the American Society for Testing and Materials (ASTM) and calcined at $700{ }^{\circ} \mathrm{C}$ for 2 hours for thermal treatment [3].

Characterization of peat clay was analyzed with XRF using a PANalytical type miniPAL4 that aimed to determine the chemical composition of minerals quantitatively. FTIR analysis was used to identify variations mineral form of each functional group that brought distinctive properties of the compounds in the peat clay. This analysis used Shimadzu models with the band range of $500-4000 \mathrm{~cm}^{-1}$ and transmittance in percent (\%). XRD patterns of peat clay obtained from the model Philips X-pert powder diffractometer using powder diffraction database file 2 (PDF-2) 1996 and X'Pert HighScore Plus software to search and match mineralogical composition qualitatively. SEM-EDX is used to identify the elements of composition and morphology of the peat clay using SEM EVO MA 10 with energy dispersive detector.

\section{Results and discussion}

\subsection{XRF characterization}

Table 1 shows the chemical content of peat clay before and after calcination. In general, the peat clay contains high minerals of silicon oxide $\left(\mathrm{SiO}_{2}\right)$, calcium oxide, iron oxide $\left(\mathrm{Fe}_{2} \mathrm{O}_{3}\right)$, titanium oxide $\left(\mathrm{TiO}_{2}\right)$, calcium oxide $(\mathrm{CaO})$ and aluminum oxide $\left(\mathrm{Al}_{2} \mathrm{O}_{3}\right)$; while other 
minerals do have only in small amounts. The similar results was also described by Mirwan et al. [3] that there are four compound of mineral with the largest number within peat clay, namely $\mathrm{SiO}_{2}, \mathrm{Fe}_{2} \mathrm{O}_{3}, \mathrm{Al}_{2} \mathrm{O}_{3}$ and $\mathrm{TiO}_{2}$ with other oxides provided in small amounts, so it is suspected that one of the major oxides can be used as an adsorbent for dyes [6] and metal ions $[7,8]$. Before the calcination process, peat clay contain higher carbon materials and lower mineral content; conversely, the minerals content led to higher values after the calcination process as seen in Table 1 . This finding is possibly due to the loss on ignition value as indicated by lower carbon material and higher mineral content after calcination. Hence, the silica oxide and aluminum oxide compounds show the significant increase of the mass composition from $18 \%$ and $7 \%$ to $32 \%$ and $18 \%$, respectively.

Table 1. Chemical composition of peat clay before and after calcination.

\begin{tabular}{|c|c|c|}
\hline \multirow{2}{*}{ Compound } & \multicolumn{2}{|c|}{ Mass composition \% } \\
\cline { 2 - 3 } & $\begin{array}{c}\text { Before } \\
\text { calcination }\end{array}$ & $\begin{array}{c}\text { After } \\
\text { calcination }\end{array}$ \\
\hline $\mathrm{SiO}_{2}$ & 18.00 & 31.90 \\
\hline $\mathrm{Fe}_{2} \mathrm{O}_{3}$ & 15.10 & 11.40 \\
\hline $\mathrm{Al}_{2} \mathrm{O}_{3}$ & 7.20 & 17.90 \\
\hline $\mathrm{K}_{2} \mathrm{O}$ & 0.80 & 0.76 \\
\hline $\mathrm{CaO}$ & 16.30 & 14.70 \\
\hline $\mathrm{TiO}_{2}$ & 9.83 & 8.72 \\
\hline $\mathrm{V}_{2} \mathrm{O}_{5}$ & 0.34 & 0.25 \\
\hline $\mathrm{Cr}_{2} \mathrm{O}_{3}$ & 2.10 & 1.57 \\
\hline $\mathrm{MnO}$ & 0.29 & 0.17 \\
\hline $\mathrm{NiO}$ & 0.30 & 0.091 \\
\hline $\mathrm{CuO}$ & 0.72 & 0.17 \\
\hline $\mathrm{P}_{2} \mathrm{O}_{5}$ & 1.70 & 0.86 \\
\hline
\end{tabular}

\subsection{FTIR characterization}

Characteristic patterns of FTIR was performed to identify variations in the mineral form of each functional group that carries characteristic constituent compounds from peat clay as shown in Fig. 1. Bands analyzed in the range of $4000-500 \mathrm{~cm}^{-1}$ have been assigned temporarily. Its pattern characteristics consisted of two treatments, i.e., before calcination and after calcination. Figure 1 and Table 2 show the possibility of the compounds of quartz, kaolinite, illite, calcite and the variation of vibration with bond of $-\mathrm{OH}, \mathrm{Si}-\mathrm{O}$ and $\mathrm{Al}-\mathrm{O}$, respectively.

The presence of quartz indicated by the vibration of Si-O stretching was performed at $1099.46 \mathrm{~cm}^{-1}, 692.47 \mathrm{~cm}^{-1}$, and $420.5 \mathrm{~cm}^{-1}$ for peaks before calcination and at $1099.46 \mathrm{~cm}^{-1}$, $694.4 \mathrm{~cm}^{-1}$, and $420.5 \mathrm{~cm}^{-1}$ for peaks after calcination [3]. However, the spectrum of peat clay indicates the possibility of water hydration in the adsorbent shown at $3421.83 \mathrm{~cm}^{-1}$ and 
$1624.12 \mathrm{~cm}^{-1}$ for bands before calcination and at $3444.98 \mathrm{~cm}^{-1}$ and $1639.55 \mathrm{~cm}^{-1}$ for bands after calcination). The presence of kaolinite is mostly shown in bands of $3421.83 \mathrm{~cm}^{-1}$, $1099.46 \mathrm{~cm}^{-1}, 777.34 \mathrm{~cm}^{-1}, 692.47 \mathrm{~cm}^{-1}, 547.8 \mathrm{~cm}^{-1}$ (before calcination) and bands of $3444.98 \mathrm{~cm}^{-1}, 1099.46 \mathrm{~cm}^{-1}, 752.26 \mathrm{~cm}^{-1}, 694.4 \mathrm{~cm}^{-1}, 547.8 \mathrm{~cm}^{-1}$ (after calcination) [9]. Illite presence was indicated bands at $3421.83 \mathrm{~cm}^{-1}, 1624.12 \mathrm{~cm}^{-1}, 777.34 \mathrm{~cm}^{-1}$ (before calcination) and $3444.98 \mathrm{~cm}^{-1}, 1639.55 \mathrm{~cm}^{-1}, 752.26 \mathrm{~cm}^{-1}$ (after calcination), whereas the presence of calcite was shown in the band $1624.12 \mathrm{~cm}^{-1}$ (before calcination) and 1639.55 $\mathrm{cm}^{-1}$ (after calcination). Lower intensity at peak of $3421 \mathrm{~cm}^{-1}$ and $1624 \mathrm{~cm}^{-1}$ after calcination was observed as compared to the intensities before calcination associated to the vaporized content of hydroxyl during calcination [10]. The sharper intensity at band of $1099 \mathrm{~cm}^{-1}$ after calcination was obtained as compared to the intensity before calcination due to the loss on ignition value as observed in XRF result. New observation of band at $777 \mathrm{~cm}^{-}$ ${ }^{1}$ in the sample after calcination was related to the new interaction between silica and alumina during calcinations; hence, it resulted in a Si-O-Al formation [11].

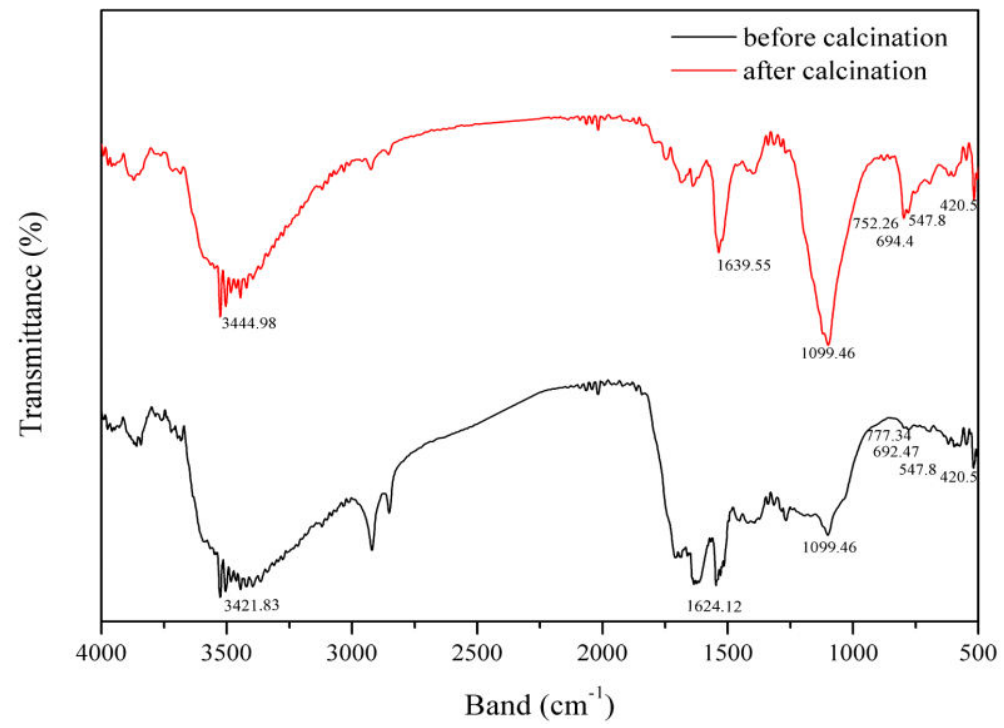

Fig. 1. FTIR spectrum of peat clay before and after calcination

Table 2. Infrared spectroscopy (IR) band peat clay before and after calcination

\begin{tabular}{|c|c|c|c|c|}
\hline \multicolumn{2}{|c|}{ Peat clay before calcination } & \multicolumn{2}{|c|}{ Peat clay after calcination } & \multirow{2}{*}{ Assignment } \\
\hline $\begin{array}{l}\text { Infrared Band } \\
\qquad\left(\mathrm{cm}^{-1}\right)\end{array}$ & $\begin{array}{c}\text { Transmittance } \\
(\%)\end{array}$ & $\begin{array}{l}\text { Infrared Band } \\
\left(\mathrm{cm}^{-1}\right)\end{array}$ & $\begin{array}{c}\text { Transmittance } \\
(\%)\end{array}$ & \\
\hline 3421.83 & 27.31 & 3444.98 & 28.1769 & $\begin{array}{l}\mathrm{H}-\mathrm{O}-\mathrm{H} \text { stretching } \\
\text { (kaolinite, illite) }\end{array}$ \\
\hline 1624.12 & 27.42 & 1639.55 & 32.3802 & $\begin{array}{l}\mathrm{H}-\mathrm{O}-\mathrm{H} \text { stretching } \\
\text { (illite, calcite) }\end{array}$ \\
\hline 1099.46 & 29.249 & 1099.46 & 26.3971 & $\begin{array}{l}\mathrm{Si}-\mathrm{O} \text { stretching } \\
\text { (kaolinite, quartz) }\end{array}$ \\
\hline 777.34 & 33.228 & 752.26 & 32.1254 & $\begin{array}{l}\mathrm{Si}-\mathrm{O}-\mathrm{Al} \text { stretching } \\
\text { (kaolinite, illite) }\end{array}$ \\
\hline
\end{tabular}




\begin{tabular}{|c|c|c|c|c|}
\hline 692.47 & 33.148 & 694.4 & 32.4748 & $\begin{array}{c}\text { Si-O-Al stretching } \\
\text { (quartz, kaolinite) }\end{array}$ \\
\hline 547.8 & 32.648 & 547.8 & 33.3652 & $\begin{array}{c}\text { Si-O-Al stretching } \\
\text { (kaolinite) }\end{array}$ \\
\hline 420.5 & 30.076 & 420.5 & 33.3815 & $\begin{array}{c}\text { Si-O stretching } \\
\text { (quartz) }\end{array}$ \\
\hline
\end{tabular}

\subsection{XRD characterization}

Characteristic XRD pattern was performed to determine the mineral composition of the peat clay before calcination and after calcination which have some similarities main compound phases, namely kaolinite, albite, sillimanite, and mullite (Fig. 2). Based on PDF21996 that mineral name of kaolinite (reference pattern number 00-001-0527 for before and after calcination) is aluminum silicate hydrate compound. Albite (reference pattern number 00-001-0739 for before and after calcination) is sodium aluminum silicate hydrate compounds. Sillimanite (reference pattern number 00-001-0614; 00-001-0626; and 00001-0627 for before and after calcination) is aluminum silicate compound. Montmorillonite (reference pattern number 00-002-0009 for before and after calcination) is aluminum iron magnesium silicate compound. It is also shown by Mirwan et al [3] that the phase of the dominant compound contained in the peat clay, namely kaolinite, and albite. While dominant compounds contained in peat clay are quartz, kaolinite, hematite, and other tridymite, illite, montmorillonite [2, 4].
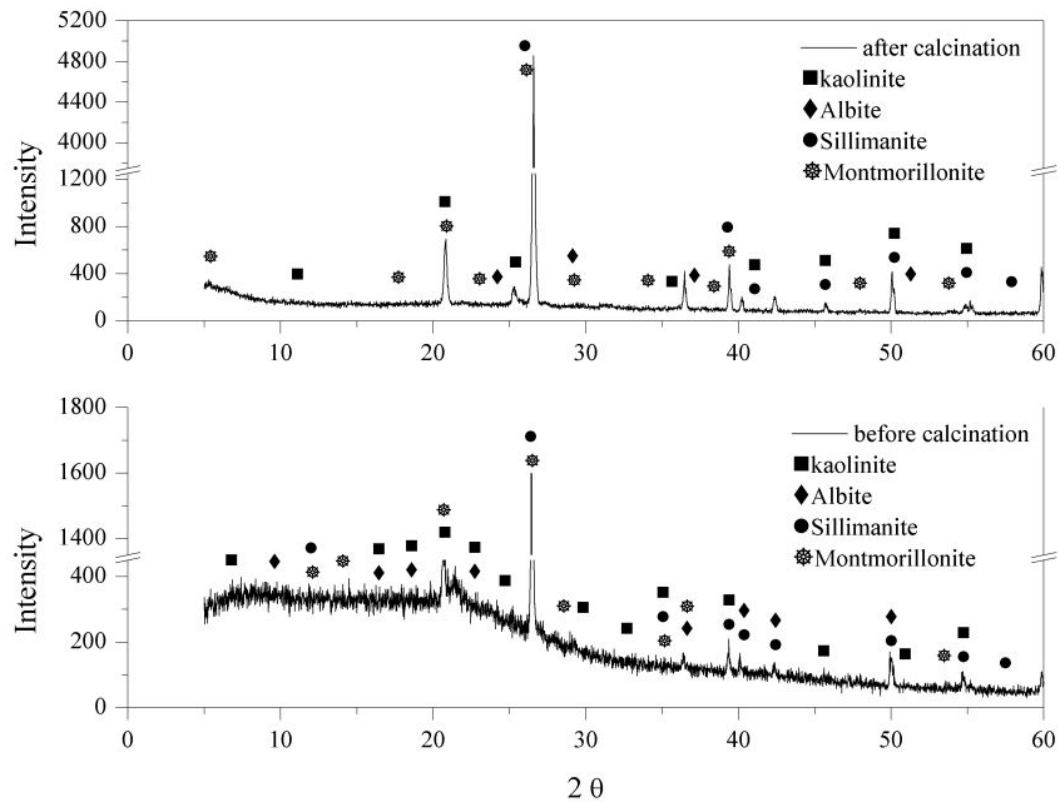

Fig. 2. XRD pattern of peat clay before and after calcination 


\subsection{SEM EDX characterization}

Flake structure of peat clay (before and after calcination) is analyzed by SEM EDX showed that the presence of the same dominant elements, namely $\mathrm{Al}, \mathrm{Si}$, and $\mathrm{Fe}$ with a composition of $2.31 \%$-wt, $5.48 \%$-wt, and $2.63 \%$-wt, respectively (before calcination) and $3.07 \%$-wt, $1.72 \%$-wt, and $3.94 \%$-wt, respectively (after calcination) (Fig. 3). Mirwan et al [3] expressed that results of analysis of peat clay from other place in South Kalimantan also contains dominant elements $\mathrm{Si}, \mathrm{Al}$, and $\mathrm{Fe}$.

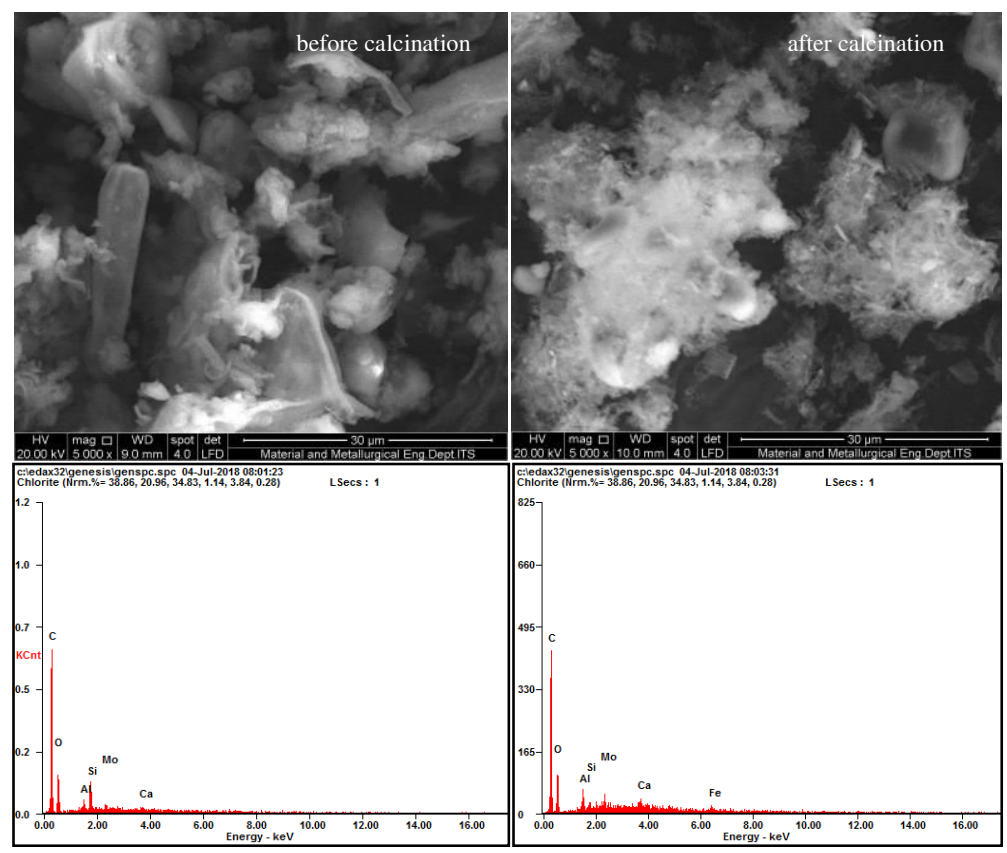

Fig. 3. Morphology SEM EDX of peat clay before and after calcination

\subsection{Future work}

Based on peat clay characteristic results, subsequent research conducted the utilization of peat clay as an adsorbent and catalyst. Besides, it can be applied as coagulant through the extraction of aluminum compound.

\section{Conclusion}

Chemical analysis with XRF showed that peat clay before and after calcination contained silica oxide, iron oxide, calcium oxide, titanium oxide, aluminum oxide in large quantities and other elements such as potassium, manganese, phosphorus pentaoxide in small quantities. FTIR analysis shows the presence of quartz, kaolinite, illite and calcite as the main phase in peat clay. The presence of these minerals further confirmed by XRD analysis. The same result is also shown by SEM EDX analysis that there are three main elements, namely $\mathrm{Al}, \mathrm{Si}$, and $\mathrm{Fe}$. The results show the potential peat clay utilized as adsorbent or catalyst. 


\section{References}

1. T. Shichi, K. Takagi, J. Photochem. Photobiol. C Photochem. Rev., 1, 2, (2000)

2. P. S. Nayak, B. K. Singh, Bull. Mater. Sci., 30, 3, (2007)

3. A. Mirwan, S. Susianto, A. Altway, R. Handogo, J. Teknol., 80, 2, (2018)

4. B. E.-D. E. Hegazy, H. A. Fouad, A. M. Hassanain, Adv. Environ. Res., 1, 1, (2012)

5. C. V. Phillips, K. J. Wills, Hydrometallurgy, 9, 1, (1982)

6. S. S. Tahir, N. Rauf, Chemosphere, 63 (2006)

7. M. A. Rauf, M. Ikram, N. Rauf, J. Trace Microprobe Techn., 20, (2002)

8. M. A. Rauf, J. Iqbal, M. Ikram, N. Rauf, J. Trace Microprobe Tech., 21, (2003)

9. S. Kaufholda, M. Hein, R. Dohrmann, K. Ufer, Vibrational Spectroscopy, 59, (2012)

10. M. D. Putra, S. M. Al-Zahrani, A. E. Abasaeed, J. Energy Chem., 22, 1 (2013)

11. M. D. Putra, Y. Ristianingsih, R. Jelita, C. Irawan, I. F. Nata, RSC Adv., 7, 87, (2017) 